Deliberationes tudományos folyóirat

14. évfolyam 1. szám 2021/1, 59-70.

Kézirat beérkezése: 2021.04.16.

Kézirat befogadása: 2021.08.16.

DOI: 10.54230/Delib.2021.1.59
Deliberationes Scienfitic Journal

Vol.14; Ed.No.1/2021, pages: 59-70

Paper submitted: 19th April 2021

Paper accepted: 16th August 2021

DOI: 10.54230/Delib.2021.1. 59

\title{
VÍRUSOS GAZDASÁG
}

Gondolatok a COVID járvány uniós és hazai gazdasági hatásairól

Árpási Zoltán, Gödör Zsuzsanna, Nyári Csaba

Gál Ferenc Egyetem, Gazdasági Kar

\begin{abstract}
Absztrakt
A koronavírus-járvány alapvetően változtatta meg a világról alkotott nézetünket. A gazdasági folyamatok ciklikusságát figyelembe véve már időszerü volt egy bizonyos fokú visszaesés, de a lezárásokkal járó pandémia jelentősen felgyorsította ezt a folyamatot. A tanulmányban azt tekintjük át, hogy milyen helyzetet teremtett mindez az unió, valamint a hazai gazdaság számára, hogyan változtak a főbb makrogazdasági mutatók, hogyan alakult az Európai Unió tagállamainak államadóssága és miként érintette a turizmus szektort a járvánnyal járó visszaesés.

Kulcsszavak: recesszió, covid és gazdaság, EU államadósság, turizmus szektor, vállalatok átalakulása,
\end{abstract}

\section{VIRAL ECONOMY}

Thoughts on the Impact of the COVID Epidemic on the EU and Domestic Economies

\author{
Zoltán Árpási, Zsuzsanna Gödör, Csaba Nyári \\ Faculty of Economy, Gál Ferenc University
}

\begin{abstract}
The coronavirus epidemic has fundamentally changed our view of the world. Taking the cyclical nature of economic processes into consideration, it was about time for a certain degree of recession, but this process has significantly been accelerated by the lockdown, triggered by the pandemic. The study examines the situation that the epidemic has created for the EU and our domestic economy, how the main macroeconomic indicators have changed, how the public debt of the EU member
\end{abstract}


states has been restructured and how the tourism sector has been affected by the downturn caused by the epidemic.

Key words: recession, Covid-19 and the economy, EU public debt, tourism sector, restructuring of businesses

\section{BEVEZETÉs}

A koronavírus-járvány kirobbanása váratlanul érte a világot. Bár már hosszú hónapok óta a levegőben volt a világgazdaságot érintő recesszió kibontakozása, a járvány azonban rendkívüli módon felgyorsította ezt a lassan formálódó folyamatot. Az alábbiakban azt tekintjük át, hogy milyen helyzetet teremtett mindez az unió, valamint a hazai gazdaság számára, hogyan változtak a főbb makrogazdasági mutatók, hogyan alakult az Európai Unió tagállamainak államadóssága és miként érintette a turizmus szektort a járvánnyal járó visszaesés.

\section{A MAKROKÖRNYEZET ÉRTÉKELÉSE}

A makrokörnyezet várható tendenciáinak értékelését nehezítik a koronavírus-járvány eddigi következményei, és a járványhelyzet jövőbeni alakulásának bizonytalanságai mint egyértelmü kockázat növelő tényezők. Ami biztos, hogy a 2019. évi adatoknak mint viszonyítási alapnak a későbbi időszakokra vonatkozóan meghatározó jelentőségük lesz. A PwC 2019-es globális válságfelmérése 19 lehetséges válságtényezőt azonosít, majd azokat 7 fö kategóriába sorolja — úgymint üzemeltetési, technikai, humanitárius, pénzügyi, jogi, valamint humán tőkével, illetve hírnévvel kapcsolatos válságtényezők. A vállalatok az általuk átélt három legsúlyosabb válságként a likviditási problémákat, a technikai hibákat és a működési zavarokat említik. Várható, hogy a jövőben a válságok még összetettebbek lesznek. (Price Waterhouse, 2020) A koronavírus-járvány mindazt újraírhatja, amit eddig a válságokról, ill. a válságok kezeléséről ezidáig megtanultunk. Ma már világosan látható, hogy a koronavírus járvány nyomán kialakuló új gazdasági helyzet differenciált módon át fogja rendezni az egyes ágazatok és gazdálkodási formák makrogazdasági pozícióit és ezeken belül a gazdasági szerveztek számát is.

A Covid-19 járvány hatásaként fontos megemlíteni, hogy olyan gyors és eddig nem tapasztalt változással járt a vállalatok működésében, amire eddig nem volt példa. (Angyal, 2020) Nyomában jelentős gazdasági átrendeződés figyelhető meg. Vannak nyertesek, mint a gyógyszeripar, az élelmiszerkereskedelem, az informatika és kommunikáció. Ezzel egyidejűleg olyan nagy vesztesei is kimutathatóak, mint a turizmus és vendéglátás, a légi közlekedés, vagy az autóipar. (Selmeci \& Márton, 2020) Bizonyos értelemben minden vállalatnak meg kell küzdenie az új helyzet kihívásaival. A válság súlyossága és hossza nagymértékben függ az üzleti szervezetek válságkezelő tevékenységének sikerességétől, a válságkezeléshez hozzárendelhető erőforrásoktól.

A helyzet néhány jelentősebb makrogazdasági adata (a teljesség igénye nélkül) a 
KSH aktuális jelentései alapján az alábbiak szerint alakult.

$\mathrm{Az}$ államadósságot illetően érdemes nemzetközi összehasonlítást is végezni. A 2019-es évre sikerült csökkenteni a korábban felhalmozott államadósságokat az Unión belül, amit az 1. ábra (Eurostat 2021, Központi Statisztikai Hivatal 2021) is jól szemléltet.

\section{1. ábra}

Az államadósság alakulása az uniós országokban a GDP százalékában (2008, 2011, 2018, 2019 éves és 2020 3. negyedév)

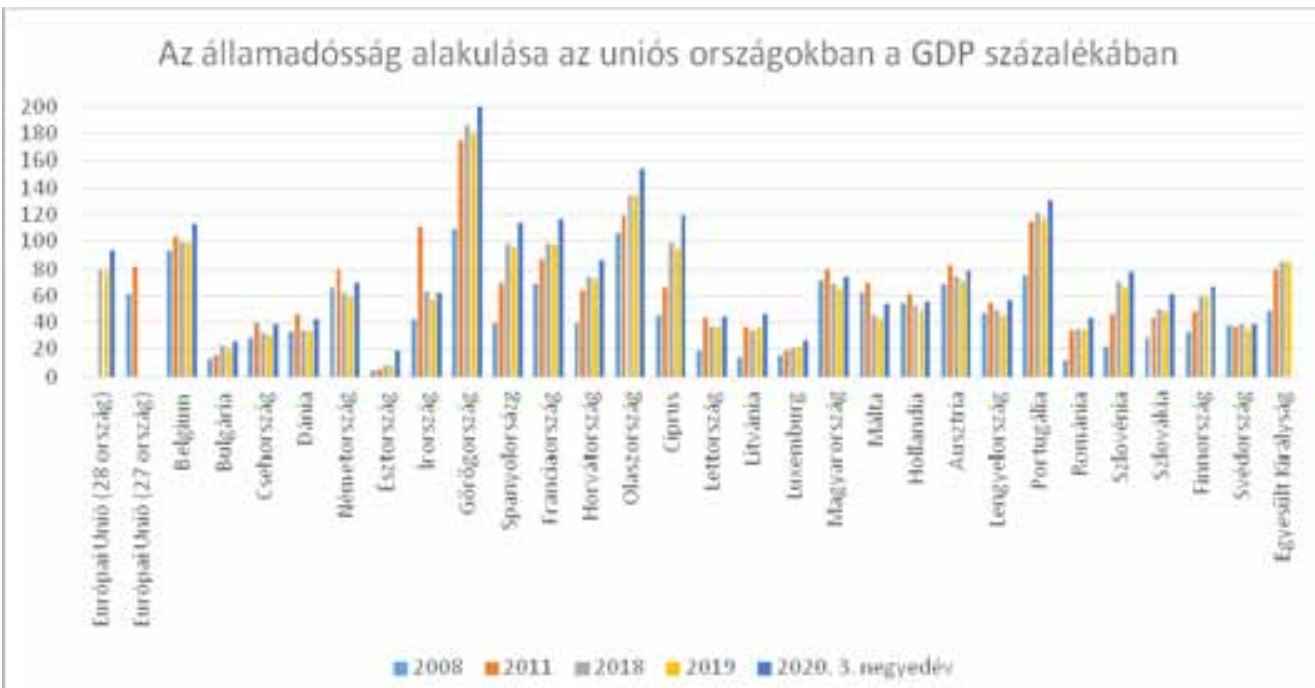

forrás: saját szerkesztés az Eurostat (2021) és a KSH (2019) adatai alapján

Jónéhány országnak, köztük Magyarországnak is sikerült jelentős sikereket elérni az államadósság leszorításában. Most ez a folyamat megszakadni látszik, mivel a 2020-as év harmadik negyedévének végére már 74,3 \% Magyarország esetében az államadósság, és vannak olyan tagállamok, amelyeknél ez az érték már meghaladja a $100 \%$-ot is. Ha a maastrichti kritériumoknak most kellene megfelelni az államadósság alapján, akkor azt csak 12 tagállam teljesítené, akik között van olyan is, amelyik nem is tagja az euró övezetnek.

A járványhelyzet jelentős hatást gyakorolt a foglalkoztatásra. A 2020. márciusmájus közötti időszakban a foglalkoztatottak száma 4,403 millió fö volt, az előzó év azonos időszakához képest 97,3 ezer fö a csökkenés (2,2\%) Közel 100 ezer fö külföldi munkahelyét vesztette el ebben az időszakban. (Központi Statisztikai Hivatal, 2020c)

2020. áprilisban a bruttó átlagkereset 400200 forint volt, 7,8\%-kal magasabb, mint 2019-ben. A koronavírus-járvány gazdasági következményeivel összefüggésben a keresetek növekedési üteme lassult, az előző év azonos időszakában mért 9\%-os növe- 
kedéshez képest. 2020. január-áprilisban a bruttó átlagkereset 388 000, a nettó átlagkereset 258000 forint volt, ez 8,7\%-kal haladta meg az előző év azonos időszakának kereseteit. (Központi Statisztikai Hivatal, 2020d)

A forint árfolyama az euróhoz viszonyítva $11 \%$-os, a dollárhoz viszonyítva $15 \%$-os gyengülést mutatott áprilisban, az elöző év azonos időszakához képest. Ugyanebben a megközelítésben az export értéke 37, az importé pedig 29 százalékkal csökkent, A termék-külkereskedelem egyenlegünk 790 millió euróval romlott.

Az ipari termelői árak együttesen májusban 1,7\%-kal meghaladták az előző év azonos időszaki árait. Az áralakulást döntően befolyásolták a koronavírus-járvány nyomán megváltozott gazdasági trendek, amelyek hatása a pénz-és árupiacokon egyaránt érezhető volt (pl. a forint árfolyamváltozásában, illetve a nyers- és alapanyagok világpiaci árában) (Központi Statisztikai Hivatal, 2020b) A kormányzati szektor 2020. első negyedéves hiányának nagysága GDP-arányosan 1,5 százalékos, 180 milliárd Ft. (Központi Statisztikai Hivatal, 2020b)

Már ez a néhány adat is előrevetíti, hogy 2020-ban elkezdődött és várhatóan továbbra is jelentős lesz a regisztrált gazdasági szervezetek számának csökkenése. Témánk szempontjából fontosnak tartjuk áttekinteni azokat a változásokat, amelyek a regisztrált gazdásági szervezetek számának alakulását jellemezték a járványt megelőző időszakban.

Az elmúlt években a gazdasági szervezetek száma Magyarországon folyamatosan emelkedett, 2015-ben 1837 704, míg 2019 végén 1945751 szervezetet regisztráltak, ami 5,87 \%-os növekedés. Az időszakon belül megfigyelhető a társas vállalkozások számának folyamatos csökkenése, ami már korábban, a 2010-es évektől kezdődő folyamat volt. Ez a folyamat részben a visszaélések korlátozása érdekében meghozott, szigorúbb cégalapítási szabályozással magyarázható, amelyet 2012 óta alkalmaznak. Ezzel párhuzamosan megfigyelhető az önálló vállalkozások részarányának emelkedése a társas vállalkozásokhoz képest. 2019 végén a vállalkozások gazdálkodási forma szerinti megoszlásában 71,3\%-os az önálló vállalkozók részaránya (1 $279135 \mathrm{db})$, a társas vállalkozások 28,7\%-os arányával szemben $(515274 \mathrm{db}$ ). Az önálló vállalkozókon belül magas, $42 \%$ az egyéni vállalkozók aránya. Érdekesség, hogy a legtöbb szervezetet az egyéb önálló vállalkozó, adószámos magánszemély kategóriákban regisztrálták.

A társas vállalkozásokon belül figyelmet érdemel a korlátolt felelőségű társaságok számának változása: 2013-ig folyamatos növekedés, majd innen csökkenés jellemző: 2013-ban $413836 \mathrm{Kft}$. volt jelen a gazdaságban, ami 2019 végére 375 884-re csökkent, közel 10 százalékponttal. A betéti társaságok száma és aránya csökkenő, a 2006-os 221152 helyett ma már 117 ezer körüli. Összességében országos átlagban tavaly ezer lakosra 184 vállalkozás jutott, melyből 131 az önálló vállalkozó és 53 a társas vállalkozás. Mindezen mutatók területi megoszlása rendkívül eltérő. (Központi Statisztikai Hivatal, 2021)

Az elmúlt öt évre jellemző, hogy bizonyos ágazatokban jelentősen, közel kétszere- 
sére emelkedett a vállalkozások száma, ezek a villamosenergia-, gáz-, és gőzellátás, ami elsősorban a megújuló villamosenergia-termelésnek, a napenergia hasznosításnak tudható be. Húzóágazat volt az építőipar, ahol öt év alatt 150\%-ra nőtt az önálló vállalkozások száma, döntő módon a kormányzati intézkedések kedvező hatására. (pl. CSOK, EU források széleskörü bevonása, kedvezőbb hitelkonstrukciók). Itt kiugró növekedést mutatott az ágazat 2019-ben, a 27\%-os áfakulcs 5\%-os mérséklése, és a Növekedési Hitelprogram hatására. Ez a terület a válság nyomán fékeződni fog, a kintlévőségek emelkedése, ezzel együtt a fizetésképtelenség esélye vélhetően növekedni fog.

A legtöbb vállalkozás továbbra is a mezőgazdaságban, a kereskedelem, szállítás, szálláshely-szolgáltatás, a tudományos, müszaki, adminisztratív tevékenység, valamint az ingatlanügyletek területén tevékenykedett. Ezek egy része a koronavírus járvány nyomán kialakuló helyzet egyértelmű vesztesének tekinthető, veszélyzónában lévő.

Szintén növekvő jelentőségű és súlyú az információ-technológiában tevékenykedő vállalkozások szerepe, 2015 és 2019 között itt 28 558-ról 37 769-re emelkedett a regisztrált vállalkozások száma.(32\%) Itt a növekedés várhatóan megmarad.

Látványos volt a film- és müsorkészítő szektor vállalkozásainak növekvő száma, az elmúlt öt évben 4577-ről 7174-re (56,7\%) Ezek a vállalkozások jelentős mértékű bizonytalanságban vannak, jórészt leálltak a járvány miatt.

Érdekesen alakul az ingatlanpiacon tevékenykedő szervezetek száma. A 2008as válság nyomán bevezetett lakáshitelezés szigorítások miatt 2011-re mélypontra kerültek, majd azóta emelkedik a számuk, amit ismét megállíthat, sőt csökkenthet a mostani vírus-helyzet piacromboló hatása. (Központi Statisztikai Hivatal, 2020)

1. táblázat

Új és megszünt vállalkozások száma gazdálkodási forma szerint

\begin{tabular}{|l|r|r|r|r|r|r|}
\hline \multirow{2}{*}{ Vállalkozások } & \multicolumn{3}{|c|}{2018} & \multicolumn{3}{c|}{2019} \\
\cline { 2 - 7 } & \multicolumn{1}{|c|}{ új } & megszünt & egyenleg & \multicolumn{1}{c|}{ új } & megszünt & egyenleg \\
\hline Egyéni & 74998 & 36217 & 38781 & 87826 & 53802 & 34024 \\
\hline Társas & 27556 & 32413 & 4857 & 28782 & 30174 & 1392 \\
\hline Összes & 125564 & 85185 & 40469 & 138112 & 98085 & 40027 \\
\hline
\end{tabular}

Forrás: saját szerkesztés a KSH (2020e) adatai alapján

A vállalkozások számának emelkedését az utóbbi években jelentős mértékben segítették a kormányzati gazdaságpolitika törekvései. Ennek köszönhetők a bevezetett kedvező hitelkonstrukciók (NHP), az építőipari áfa-csökkentés és a családtámogatás, ezek közvetett módon az építőipar és az ingatlanügyletek fellendülésében játszottak szerepet. A vállalkozások nyereségességét, növekedési pályáját javító előnyösebb 
adózási formák (pl. KATA, KIVA) is megnövelték a vállalkozási kedvet, így azok számát is, emellett lényegesen segítették a gazdasági szereplők adó-moráljának javulását. Míg 2013-ban e két adózási formát 15841-en választották, 2018-ban már 56274-en. Ezen adózási formák hozzájárultak ahhoz is, hogy sok korábbi alkalmazott vált önfoglalkoztatóvá. (Központi Statisztikai Hivatal, 2020c)

Érdekes kettősség, hogy 2019-ben az előző évhez képest 10 százalékkal több új vállalkozást regisztráltak (138 000), ugyanakkor a megszünések száma is növekedett, utóbbi 15 százalékkal, számszerűen 98 000-re.

Érdemes áttekinteni, hogyan alakultak a megszűnés egyes esetei a társas vállalkozások körében. Feltehetjük magunknak azt a kérdést is, lehet-e párhuzamokat vonni a korábbi évek tendenciái és napjaink válságának következményei között?

2. táblázat

Társas vállalkozásokat lezáró eljárások számának alakulása (adatok: db)

\begin{tabular}{|l|r|r|r|r|r|r|}
\hline \multirow{2}{*}{ Eljárások } & \multicolumn{7}{|c|}{ Évek } \\
\cline { 2 - 7 } & \multicolumn{1}{|c|}{$\mathbf{2 0 0 8}$} & \multicolumn{1}{c|}{$\mathbf{2 0 1 0}$} & \multicolumn{1}{c|}{$\mathbf{2 0 1 2}$} & \multicolumn{1}{c|}{$\mathbf{2 0 1 4}$} & \multicolumn{1}{c|}{$\mathbf{2 0 1 7}$} & \multicolumn{1}{c|}{$\mathbf{2 0 1 9}$} \\
\hline felszámolás & 24169 & 30487 & 42145 & 31370 & 14058 & 10324 \\
\hline végelszámolás & 17116 & 21263 & 33305 & 22290 & 9775 & 10226 \\
\hline kényszertörlés & - & - & - & 20835 & 16809 & 19958 \\
\hline együtt & 41285 & 51750 & 75450 & 74495 & 40642 & 40508 \\
\hline
\end{tabular}

Forrás: saját szerkesztés a KSH (2020e) adatai alapján

A felszámolási eljárások száma 2008-tól 2012-ig minden évben jelentősen emelkedett, ezt követően 2019-ig folyamatosan csökkent. Az adott időszak egészében 47,3\%os visszaesés figyelhető meg. A tendencia hasonló a végelszámolások esetén is, a közel tíz év alatt összességében 40 \% körüli az eljárások számának csökkenése. Az időszak adatai alapján kijelenthető, hogy a 2008-as válság nyomán elindult egy megszűnési hullám, amely 2012-ben érte el csúcspontját, ebben az évben több mint 75000 társas vállalkozás zárult le. Vagyis a pénzügyi válság késleltetett reálgazdasági hatásai elhúzódva, négy éven át növelték a felszámolások és végelszámolások nagyságát. A gazdasági konjunktúra 2016-tól érezteti a hatását, a végelszámolások száma gyakorlatilag alig változik, a felszámolásoké csökken. A 2014-ben bevezetett kényszertörlések száma 20 835-ről 2019-re 19 958-ra csökkent, alig módosult, egy kiugró adat van, 2015-ben 26577.

Várhatóan 2020-ban és az azt követő néhány évben a koronavírus-járvány következtében - hasonlóan a 2008. utáni időszakhoz - a felszámolási eljárások és a végelszámolások száma jelentősen emelkedhet.

A csődeljárások száma nagyon alacsony a magyar vállalkozások válságkezelési gyakorlatában. A közeli jövő izgalmas kérdése lehet, hogy a vállalkozások milyen 
mértékben fedezik fel, tudnak-e élni ennek lehetöségével 2020-ban és azt követően is?

\section{GLOBÁlis ÉS HAZAI TRENDEK A TURIZMUSBAN - HELYZETELEMZÉS ÉS KILÁTÁSOK}

A koronavírus okozta járvány a fentiekben ismertetett makrotrendek negatív irányú kibontakozását hozta magával. A különböző nemzetgazdasági szektorokat eltérő mértékben, ám egységesen kedvezőtlenül érintette. Ezek közül globálisan talán a leginkább figyelemre méltó a turisztikai ágazatban bekövetkezett változások elemzése és az esetleges megoldási lehetőségek átgondolása. Ahogy az a járvány utáni gazdasági talpraállást illetően sem egyértelmü, úgy az idegenforgalmat érintően talán még kérdőjelesebb, hogy milyen dinamikával talál majd az ágazat magára.

A járvány drámai berobbanásának megakadályozására meghozott nemzetközi korlátozó intézkedések egyértelműen legnagyobb vesztese a turizmus és vendéglátás szektor volt. Magyarországon ez 2020. márciusával kezdődően azzal járt, hogy a szálláshelyek hónapokra bezártak. A vendéglátóegységek pedig - amennyiben adottságaik és lehetőségeik ezt engedték - házhozszállításra tértek át. A munkaadók jelentős része bízott abban, hogy a néhány hónapos lezárás meghozza eredményét és a nyári szezontól kezdődően már újra normális mederben müködtethetik vállalkozásaikat. Nem így lett. A nyári enyhítésnek ugyan szükségszerüen volt forgalomélénkítő hatása, de az ősz újabb szigorítások meghozatalát tette indokolttá. Mindez az állami támogatások ellenére is sok szolgáltatót sodort bizonytalan helyzetbe.

A szektorban dolgozók ugyanis az első hullám idején - bízva a kialakult helyzet átmeneti jellegében - többnyire állományban maradtak. Idővel azonban vagy elbocsátások áldozatai lettek vagy saját maguk döntöttek a bizonytalan helyzet megszüntetése mellett és kerestek más területen állást. Így az a szomorú munkaerőpiaci helyzet alakult ki, hogy képzett és gyakorlati tudással rendelkező szakemberek a turisztikai vagy vendéglátó szakmát maguk mögött hagyva más ágazatokban helyezkedtek el.

A nyári szezonokra egyébként is jellemző volt a vendéglátó szakmában jártas képzett szakemberek iránti megnövekedett igény, mindez a helyzet azonban a vélhetően jelentős számú pályaelhagyó miatt tovább fokozódik. Míg jelenleg nem, vagy csak jelentősen csökkentett kapacitással üzemelnek a szálláshelyek, addig az enyhítések nyomán létrejövő fokozódó utazási kedv miatt újfent szakemberhiány léphet fel. Ezek egy része azonban már elhelyezkedett máshol és nem feltétlenül kíván visszatérni egy látszólag törékeny szektorba. 


\section{3. táblázat}

A kereskedelmi szálláshelyek külföldi és belföldi vendégforgalma

\begin{tabular}{|c|c|c|c|c|c|c|}
\hline \multirow{2}{*}{ EV } & \multicolumn{3}{|c|}{ Vendlost } & \multicolumn{3}{|c|}{ Vendigojazakik } \\
\hline & Beyolat & Kaltold & Oscresen & Betfond: & Kalloid & Orszesen \\
\hline \multicolumn{7}{|c|}{ Srama, ezer } \\
\hline 2001 & 3003 & 3070 & 6073 & 7754 & 10894 & 18648 \\
\hline 2002 & 3163 & 3013 & 6176 & 8089 & 10361 & 18450 \\
\hline 2003 & 3367 & 2948 & 6315 & 8571 & 10040 & 18611 \\
\hline 2004 & 3346 & 3270 & 6616 & 8391 & 10500 & 18899 \\
\hline 2005 & 3618 & 3446 & 7064 & 8958 & 10779 & 19737 \\
\hline 2006 & 3873 & 3310 & 7183 & 9606 & 10046 & 19652 \\
\hline 2007 & 4023 & 3451 & 7474 & 9957 & 10171 & 20128 \\
\hline 2008 & 4135 & 3516 & 7651 & 9964 & 10010 & 19974 \\
\hline 2009 & 3923 & 3228 & 7151 & 9490 & 9220 & 18710 \\
\hline 2010 & 4011 & 3462 & 7473 & 9940 & 9614 & 19554 \\
\hline 2011 & 4199 & 3822 & 8021 & 10205 & 10411 & 20616 \\
\hline 2012 & 4221 & 4164 & 83 BS & 10413 & 11392 & 21805 \\
\hline 2013 & 4497 & 4388 & 8885 & 10985 & 11963 & 22968 \\
\hline 2014 & 5022 & 4618 & 9640 & 12082 & 12351 & 24434 \\
\hline 2015 & 5474 & 4929 & 10400 & 12925 & 12962 & 25883 \\
\hline 2016 & 5815 & 5302 & 11117 & $13 \mathrm{8} 27$ & $13 \mathrm{gop}$ & 27629 \\
\hline 2017 & 6234 & 5650 & 11804 & 14827 & 14942 & 29769 \\
\hline 2018 & 6603 & 5945 & 12548 & 15671 & 15340 & 31011 \\
\hline 2019 & 6752 & 6169 & 12920 & $157 \mathrm{es}$ & 15759 & 31538 \\
\hline $2020^{a}$ & 4012 & 1366 & 5378 & 9916 & 3774 & 13690 \\
\hline
\end{tabular}

Forrás: a KSH (2020a) adatai alapján

A 3. táblázat adatai jól mutatják azt a sokkszerű visszaesést, amely a 2020-as esztendőben történt. Látható, hogy míg a belföldi turizmus a nyári nyaralásoknak köszönhetően, „csak” 40\%-kal csökkent, addig az egész évre vonatkozóan a külföldi vendégek száma és ezzel együtt a vendégéjszakák száma is közel $80 \%$-kal csökkent. Mindez azért is jár súlyos hatással, mert a korábbi évek eredményei jól tükrözik, hogy hagyományosan $50-50 \%$ a megoszlás a szektor egészét nézve, azaz a felét a belföldi, felét pedig a külföldi turisták adják. A jövőre nézve pedig valószínűleg a külföldi vendégek visszacsábítása lesz a komolyabb kihívás, viszont rájuk (is) az ágazatnak feltétlenül szüksége van.

\section{HOGYAN TOVÁBB TURIZMUS?}

Szinte már közhelyszámba megy a kijelentés, de a járvány rabságában töltött elmúlt több mint egy év valószínűleg alapvetően formálja majd át az emberek gondolkodását, értékrendjét és fogyasztási szokásait. A turizmus magára találásának lendületét alapvetően több tényező is befolyásolni fogja. Mindenképpen külön kell választani a belföldi és a külföldi vendégek utazásait. A korábbiakban bemutatott jellemzők alapján is jól látszik, hogy a vírushelyzet idején a külföldi látogatók száma csökkent a legdrámaibb módon. Köszönhető mindez annak, hogy szigorúbb határellenőrzéseket foganatosítottak, illetve az elmúlt év jelentős részében többnyire 10-12 nap karantén 
várt a beutazókra (vagy ennek a veszélye fennállt). Ilyen feltételek mellett az utazók többsége érthető módon távol maradt a külföldi desztinációktól és a hazait preferálta.

A nemzetközi utazások számának növekedését alapvetően a jövőt illető bizonytalanság teszi megkérdőjelezhetővé. Jelen pillanatban ugyanis nincs információ a határok nyitását illetően, az utazásokhoz kapcsolódó feltételek, szabályokat illetően, de még azt sem tudni, hogy mely oltásokkal lehet minden bizonnyal külföldre utazni. A WHO ajánlásait nem minden ország kezeli egységesen és így lehetnek majd jelentős eltérések. Bár az bizonyos, hogy azon országok, amelyek esetén a GDP döntő részét a turizmus adja, a szabályok nem fogják szűkíteni a beutazók lehetséges számát. A körülményekhez képest a legnagyobb rugalmassággal fogják körülhatárolni ezeket a feltételeket. Görögország már 2021 áprilisában kihirdette, hogy május 14-től megnyitják a határokat és bármilyen oltással, antitest igazolással vagy negatív teszttel be lehet menni majd az országba. (Indul az előszezon.)

Mindeközben a Svájcba érkezőkre kivétel nélkül 14 nap karantén vár, akármilyen igazolással is rendelkeznek. Ezek a szabályozások természetesen hétről hétre változnak/változhatnak, de ettől függetlenül jól tükrözik a szektorral szemben álló mérhetetlen bizonytalanságot. A bátrabbak már minden bizonnyal elkezdték foglalni a nyári nyaralást, ám a többség inkább kivár. Aminek pozitív következménye talán az lehet, hogy később majd a biztonságosabbnak vélt belföldi desztinációkat fogják elönyben részesíteni.

Ezzel a gondolattal el is jutottunk a másik fontos tényezöhöz. Ez pedig a belföldi turisták utazási hajlandóságával függ össze. Az kétségtelen, hogy a pandémia és az ezzel járó korlátozások miatt az emberek türelme és kitartása már a végét járja. Meglátszik ez a bevezetett óvintézkedések betartásán is, ha összevetjük a 2020 tavaszi és az egy évvel későbbi időszak megnyilvánulásait. Mindez talán érthető emberi reakció. Viszont együtt járhat egy megnövekedett utazási vággyal is, amely jót tesz majd a szektornak. Várhatóan a szigorítások folyamatos enyhülésével a nyári szezon az elmúlt évekhez hasonlóan lényegesen erősebb lesz és az újfent megjelenő keresletre megfelelö ajánlatokkal tudnak majd reagálni a szolgáltatók. Mint az több forrásból ismert, a szállodákat, gyógy- és strandfürdőket üzemeltetők komoly kampányokkal készülnek a belföldi turisták megnyerésére. Különösen azért, mert nem tudni, mit hoz az ősz és így egy erős nyár a túlélés záloga lehet. 


\section{2. ábra}

A nemzetközi turista érkezések alakulása 2020-ban és a lehetséges forgatókönyvek 2021-re.

\section{International Tourist Arrivals in 2020 and Scenarios for 2021 (y-0.y monthly change, \%)}

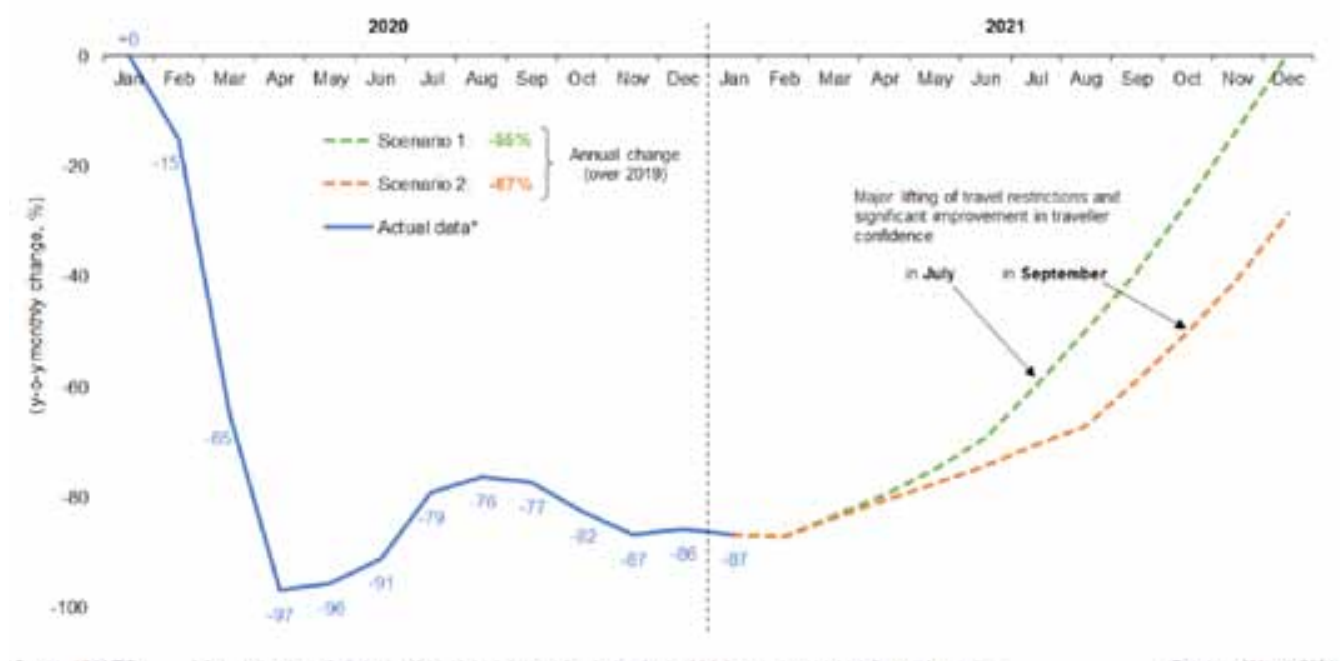

Forrás: World Tourism Organization (2020a)

A 2. ábrán látható a turizmus globális felfutásának feltételezett íve, attól függően, hogy július vagy szeptember hónapban jönnek-e az utazásokra vonatkozó enyhítések. Az mindenképpen jól látható, hogy a számok és a tendencia alapján már a mélypontot elérte az ágazat és erőteljesen a nyári nyitásra összpontosít. Az előrejelzések alapján év végére magára találhat a szektor, ami a 2022-es esztendőben talán újra az elmúlt évtizedekben tapasztalható növekedési pályára állhat, ám a 2019-es szint elérésére legalább 2,5-4 évet vélhetően várni kell (World Tourism Organization, 2020b).

Az pedig majd egy másik, jövőbeni elemzés témája lehet, hogy mennyire változtunk meg mi fogyasztók az elmúlt években és tudjuk-e ott folytatni, ahol abbahagytuk, vagy esetleg gyökeresen megváltoztak az igényeink, vágyaink, aggodalmaink, félelmeink.

\section{ÖsSZEGZÉS}

Az Európai Uniót sem kerülte el a járvány, ennek következtében a legtöbb ország szükségesnek látta a rendelkezésére álló gazdaságpolitikai eszközeinek bevetését. Elsődleges célok közt szerepelt a munkahelyek, valamint a gazdaságok müködőképességének biztosítása. Az ezekhez szükséges források nem egyformán álltak/állnak a tagállamok rendelkezésére. A 2008-as gazdasági világ válság után jelentős mértékben emelkedtek az 
országok adósságai, amiben jelentős szerepe volt a kormányok gazdaságpolitikájának is. A válság rámutatott arra, hogy milyen sebezhető is lehet egy gazdaság, ha nem tud megfelelő válaszokat adni a kihívásokra. Az adósságnövekedés egyben figyelmeztetés is volt az országok számára, hiszen azok, akik már korábban is magasabb adóssággal rendelkeztek, pl. a maastrichti kritériumokat meghaladó volt annak mértéke, sokkal nehezebb helyzetbe kerültek. Ilyen válságot a modern kori gazdaságtörténet még nem tapasztalt, így nehéz az előrelátás. A válság természetét is nehéz megítélni: éppúgy lehet elhúzódó, vagy gyors lefolyású, mint esetleg hirtelen felugró. A tanulmányban ismertetett makrogazdasági mutatók is jól alátámasztják a helyzet komolyságát. A válság által egyik leginkább érintett szektor a turizmus, amelynek az újbóli növekedési pályára állítása hosszú hónapokat, éveket vehet igénybe. Annyi biztos, hogy ez a történet még jelenleg is íródik és egyelöre nehéz meghatározni a lecsengését. Az oltások felvételével talán visszatérhet az élet végre a normál kerékvágásba, de a gazdaságnak még minden bizonnyal több időre lesz szüksége, mire kiheveri a Covid mellékhatásait. Az MNB ugyanakkor jól reagált a válságra és post-COVID szindróma helyett teljes felépülést prognosztizál (MNB 2021.). Reméljük igaza lesz.

Kapcsolattartó szerzö:

Corresponding author:

Árpási Zoltán

Zoltán Árpási

Gál Ferenc Egyetem, Gazdasági Kar

5600 Békéscsaba

Bajza u. 33.

arpasi.zoltan@gfe.hu

Faculty of Economy, Gál Ferenc University

Bajza str. 33.

5600 Békéscsaba, Hungary

arpasi.zoltan@gfe.hu

\section{IRODALOMJEGYZÉK:}

Angyal, A. (2020). A koronavírus felgyorsithatja az ipari forradalmat. https://index. hu/gazdasag/penzbeszel/2020/04/23/a_koronavirus_felgyorsithatja_az_ipari_forradalmat/

Eurostat - General Government Gross Debt - (2021. 02.08) https://ec.europa.eu/ eurostat/databrowser/view/sdg_17_40/default/table?lang=en

Központi Statisztikai Hivatal. (2019). Magyarország, 2019. I-III. negyedév. https:// www.ksh.hu/docs/hun/xftp/idoszaki/mone/mo1909.pdf

Központi Statisztikai Hivatal. (2020a). A kereskedelmi szálláshelyek külföldi és belföldi vendégforgalma. https://www.ksh.hu/stadat_files/tur/hu/tur0017.html

Központi Statisztikai Hivatal. (2020b). Ipari termelöi árak, 2020. május. KSH Gyorstájékoztató, 2020. június 30.http://www.ksh.hu/docs/hun/xftp/gyor/tar/tar2005.html

Központi Statisztikai Hivatal. (2020c). Foglalkoztatottság, 2020. március-május. KSH Gyorstájékoztató, 2020. június 29. http://www.ksh.hu/docs/hun/xftp/gyor/fog/ fog2005.html 
Központi Statisztikai Hivatal. (2020d).Keresetek, 2020. január-április. KSH Gyorstájékoztató, 2020. június 30. http://www.ksh.hu/docs/hun/xftp/gyor/ker/ker2004.html

Központi Statisztikai Hivatal. (2020e). A regisztrált gazdasági szervezetek száma, 2019. KSH Statisztikai Tükör, 2020. április 30. http://www.ksh.hu/docs/hun/xftp/ idoszaki/gazd/2019/index.html

Központi Statisztikai Hivatal. (2021). A regisztrált gazdasági szervezetek száma. http://www.ksh.hu/docs/hun/xstadat/xstadat_eves/i_qvd010.html

Magyar Nemzeti Bank. (2021). Világjárványtól az újraindításig. Az MNB válságkezelő lépései. Magyar Nemzeti Bank tanulmánykötet, 2021. július

Price Waterhouse. (2020). A válságkezelési felkészültség, mint a jövö versenyelönye: 4 500 válság tanulságai. A PwC 2019-es globális válságfelmérése. https://www.pwc. $\mathrm{com} / \mathrm{hu} / \mathrm{hu} / \mathrm{kiadvanyok} / \mathrm{assets} / \mathrm{pdf} / \mathrm{global}$ crisis_survey_2019.pdf

Selmeci, P., \& Márton, B. (2020). Lépéskényszerben a vállalkozások - Gyors válaszok a rendkívüli kihívásokra. Világgazdaság, 2020. 05.26. https://www.vg.hu/ velemeny/elemzes/lepeskenyszerben-a-vallalkozasok-gyors-valaszok-a-rendkivulikihivasokra-2-2281473/

World Tourism Organization (2020a). International Tourism and COVID-19 https:// www.unwto.org/international-tourism-and-covid-19

World Tourism Organization (2020b). Impact assessment of the covid-19 outbreak on international tourism https://www.unwto.org/impact-assessment-of-the-covid-19outbreak-on-international-tourism 